\title{
GENETIC INFORMATION, OBESITY, AND LABOR MARKET OUTCOMES
}

\author{
EDWARD C. NORTON ${ }^{\mathrm{a}, \mathrm{b}, *}$ and EUNA HAN ${ }^{\mathrm{c}}$ \\ ${ }^{a}$ Department of Health Management and Policy, University of Michigan, Ann Arbor, MI, USA \\ ${ }^{\mathrm{b}}$ Department of Economics, University of Michigan, Ann Arbor, MI, USA \\ ${ }^{\mathrm{c}}$ Institute for Health Research and Policy, University of Illinois at Chicago, Chicago, IL, USA
}

\begin{abstract}
SUMMARY
Economists have argued that obesity may lead to worse labor market outcomes, especially for women. Empirical methods to test this hypothesis have not thus far adequately controlled for the endogeneity of obesity. We use variation in genotype to predict variation in phenotype (obesity). Genetic information from specific genes linked to obesity in the biomedical literature provides strong exogenous variation in the body mass index and thus can be used as instrumental variables. These genes predict swings in weight of between 5 and 20 pounds for persons between five and six feet tall. We use additional genetic information to control for omitted variables correlated with both obesity and labor market outcomes. We analyzed data from the third wave of the Add Health data set, when respondents are in their mid-twenties. Results from our preferred models show no effect of lagged obesity on the probability of employment or on wages, for either men or women. This paper shows the potential of using genetic information in social sciences. Copyright (C) 2008 John Wiley \& Sons, Ltd.
\end{abstract}

Received 8 October 2007; Revised 23 April 2008; Accepted 29 April 2008

KEY WORDS: obesity; genetics; labor market outcomes; employment; wages; Add Health

\section{INTRODUCTION}

Over the last several decades, the obesity rate among American adults has risen steadily. The majority are now overweight. The economic consequences of obesity, beyond worsening morbidity and mortality, may include worse probability of employment and lower wages. Obesity may affect these labor market outcomes because employers may want to avoid obese employees if obese employees have lower productivity due to their obesity, higher health-care costs, or a higher discount rate manifested by lower investment in human capital (Baum and Ford, 2004). On the demand side, consumers may shun obese employees, particularly in service industries.

For all these reasons, economists have tried to measure empirically how obesity affects wages (e.g. Averett and Korenman, 1996; Cawley, 2000; Behrman and Rosenzweig, 2001; Baum and Ford, 2004; Cawley, 2004; Conley and Glauber, 2005; Han et al., 2008). The results vary widely, in part due to different econometric methods to deal with endogeneity. The early studies of obesity on labor market outcomes ignored the endogeneity of obesity, making causal inference impossible. More recent studies have used weak instruments or just-identified models. Therefore, finding good instruments for obesity would advance the field. *Correspondence to: Department of Health Management and Policy, 109 S. Observatory St., University of Michigan, Ann Arbor,
MI 48109-2029, USA. E-mail: ecnorton $@$ umich.edu 
This study uses genetic information to identify the effect of obesity on labor market outcomes. Genes that change the propensity of a person to be obese provide natural variation, as long as those genes are not correlated with other behavioral factors. Instrumental variables created from this genetic information allow us to control for the endogeneity of obesity and obtain consistent estimates of the causal effect of obesity on labor market outcomes. In addition, genetic information that is correlated with obesity - but also is correlated with the main outcome - still helps reduce omitted variable bias. Genetic information holds great promise for social science research. Many large surveys now routinely collect biomarkers, including genetic information. In the past, economists have used information on siblings and twins as controls or instruments by appealing to the argument that biological siblings and twins share many genes. Using genetic information can greatly improve on this approach if the genes are targeted to the endogenous variable, as they are in our study.

Studies in behavioral genetics suggest that the genetic effect on variation in body mass index (BMI) is relatively strong. Correlations in BMI of monozygotic twins reared apart are similar to those for monozygotic twins reared together, suggesting a dominant genetic effect on BMI (Stunkard et al., 1990; MacDonald and Stunkard, 1990; Price and Gottesman, 1991). Furthermore, genes are plausibly exogenous, being determined at conception. As the first published economic study that we know of to use genetic information, we also discuss the limitations of genetic information.

We analyze data from the National Longitudinal Study of Adolescent Health (Add Health). In Wave III of Add Health, a subset of 2612 of the Add Health respondents (total of about 17000) contributed DNA samples. Six genes identified from the DNA samples were chosen specifically because they are believed to be related to obesity and to have a relatively high prevalence in the population. Polymorphisms in these six genes have been linked to obesity through behavior (Blundell, 1977; Hoebel et al., 1989). All affect how the central nervous system regulates satiation and eating behavior. Several pass all specification tests for good instruments; others were used to control for omitted variable bias.

Results from our preferred models show no statistically significant effect of lagged BMI on either the probability of employment or wages conditional on employment, for either men or women. The genetic information provides strong instrumental variables, but in our sample of adults in their mid-twenties, lagged measures of obesity are generally not endogenous.

\section{BACKGROUND}

\subsection{Obesity}

Annual trends show that average BMI increased by 9\% during 1984-1998 and that the number of obese adults more than doubled during the same period (Chou et al., 2004). The increase in the proportion of being overweight and obese affects all ages, racial, and ethnic groups, and both genders (US Department of Health and Human Services, 2001). The prevalence of obesity is higher than that of smoking, use of illegal drugs, or other risk factors for most of the highly prevalent chronic diseases, including heart disease, diabetes, and cancer (Philipson, 2001).

Baum and Ford (2004) identified four ways that obesity affects labor market outcomes. First, low productivity of obese people may result from their health problems directly associated with obesity. The previous literature has consistently reported health problems and a high health-care cost caused by obesity (Wolf and Colditz, 1998; Finkelstein et al., 2003; Long et al., 2006). Second, individuals may discount the future heavily. Food consumption brings immediate gratification, while costs of overconsumption of food occur in the future (Cutler et al., 2003). Therefore, myopic workers are less likely to be concerned about the long-term adverse health effects of consuming fattening foods than nonmyopic workers, and accordingly, more likely to be obese (Cawley, 2000). Like the choice for food consumption, those people will ignore future returns to the investments on their human capital, such as on-the-job training, when they make decisions about current consumption of those investments. Third, 
there may be some occupations where non-obese workers are more productive than obese workers due to consumer-based discrimination against obese workers. Fourth, employers may have a distaste for obese employees for reasons including their own preferences for lean employees, consideration of their consumers' distaste for obese workers, or their concerns about rising employer-provided healthinsurance costs.

Collectively, these argue that obesity should reduce the probability of employment and wages conditional on employment, if there is any effect at all. Furthermore, the marginal effect of an increase in BMI may differ at different ends of the spectrum, being perhaps positive for waifs and negative for the vast majority who are in the normal to high weight range. We are not able to test the relative strengths of the contributions of each factor in our model. But we do acknowledge that in our data set of young men and women, the long-term health costs are probably least important. Like the prior empirical work, we are interested in estimating the overall effect of obesity on labor market outcomes.

\subsection{Prior empirical work}

The first several studies that linked obesity to labor market outcomes all used the same data, the NLSY79 (Register and Williams, 1992; Loh, 1993; Pagan and Davila, 1997; Gortmaker et al., 1993; Sargent and Blanchflower, 1994). However, their results differ markedly, perhaps due to the lack of valid control for the endogeneity of obesity.

More recent studies have tried to control for the endogeneity of obesity. Averett and Korenman (1996) replaced current body weight with lagged body weight and also controlled for sister-fixed effects. Similarly, Conley and Glauber (2005) took the 13 and 15 year lag of BMI as instruments for the current BMI and used sibling fixed effects. Behrman and Rosenzweig (2001) used an identical twin fixed-effects model along with lagged consumption and lagged physical characteristics as instruments for current BMI and height. Cawley (2000) used a women's own child's body weight as an instrument for the sample women's body weight. Cawley (2004) estimated individual and sibling fixed-effects models and also used the sibling's body weight as an instrument. Baum and Ford (2004) and Han et al. (2008) controlled for individual fixed effects, but did not use instrumental variables. Often these instruments are weak or just identified. Although sibling fixed effects sweep out unobserved permanent factors at the family level, individual factors that may affect both obesity and labor market outcomes remain in the error term. Some of these studies found negative effects of obesity on wages (Averett and Korenman, 1996; Conley and Glauber, 2005; Cawley, 2004; Han et al., 2008) while the others found no statistically significant effects.

In two recent papers, Morris $(2006,2007)$ also assesses how BMI and obesity affects employment and earnings. His methods are noteworthy both because he uses data from England instead of the US, and because he uses area-level variables for instruments to control for environmental factors affecting individual obesity in the form of endogenous and exogenous peer group effects. In one study, he used the mean proportion of adults classified as obese in the respondent's health authority; in the other study, he added the mean BMI in the respondent's health authority as an additional instrumental variable. He finds negative effects of obesity on employment for men and women and a negative relationship between BMI and earnings for women. The results are statistically significant when not controlling for endogeneity, but the significance disappears in IV models.

\subsection{Value added of study}

No prior empirical work has used genetic information to identify the effect of obesity on labor market outcomes. Two other economic paper use genetic information as instrumental variables to study how health affects education (Ding et al., 2006; Fletcher and Lehrer, 2008). Otherwise, economists have only used knowledge of family history of disease (Brown et al., 2005). Compared with prior studies analyzing the effect of obesity on labor market outcomes, ours has several important advantages. We use genetic 
information to control for some otherwise unobservable hereditary traits that affect either obesity or labor market outcomes, or both. The variables that affect only obesity serve as instrumental variables; the others are exogenous controls. By having multiple instruments, we also test whether sibling's BMI, which has frequently been used as a lone identifying instrument, validly passes the over-identifying restrictions, conditional on the genetic information variables being valid. Through these methods we can better answer the empirical question that many economists have tried to answer - what is the marginal effect of BMI on the probability of employment and on wages?

\subsection{Genetics}

To understand this study, we must explain a few key concepts of genetics. A gene is a unit of heredity, consisting of a string of DNA. Functionally, genes regulate the production of proteins. Because human chromosomes, which are strings of genetic material divided into genes, come in pairs, each gene has two copies. Alleles are variations of the same gene. Humans have two alleles of each gene. The genotype is the specific genetic makeup of an individual. The genotype combined with environmental factors produce observable characteristics called phenotypes, such as whether or not a person has blue eyes or is obese. An individual's two alleles may be the same, but often differ. When two alleles differ, one may be dominant and one recessive, such as for eye or hair color. Or the phenotype may depend on the combined alleles in another manner, possibly also depending on the environment.

A number of genes have been linked to obesity in the biomedical literature (Comuzzie and Allison, 1998; Snyder et al., 2004). However, it is not as simple as there being a 'fat' gene or a 'skinny' gene. Instead there is a complex relationship between neurotransmitters in the brain, genes, and obesity. Neurotransmitters, including dopamine and serotonin, regulate food intake, and are thus related to obesity (Guo et al., 2006). Certain genes interact with these neurotransmitters. Furthermore, the interaction depends on the exact genotype, with certain polymorphisms of genes related to high obesity and others to low obesity.

The Add Health data set has information on six relevant genes chosen because they have a high prevalence in the population and a direct role in either dopamine or serotonin. Furthermore, each gene has been shown in epidemiologic literature to be related to obesity (Guo et al., 2006). In the Add Health data, we created genetic variables based on whether an individual had a particular genotype in either allele. Several of these variables are highly correlated to obesity, as described later. Because genes related to neurotransmitters may also affect other behaviors besides those leading directly to obesity, we were not surprised to find that some of our genetic variables were directly related to labor market outcomes.

\section{METHODS}

We investigate the role of obesity in two labor market outcomes. One is the probability that the person is employed, defined as working at least 10 hours per week at the time of the interview or currently enrolled in school. The other outcome is wages, conditional on working. For both the models, we are primarily interested in the effect of a change in lagged BMI on the outcomes, holding other demographic factors constant. The literature review suggests that a person with higher lagged BMI is less likely to be employed and those that are employed are expected to have lower wages.

For the probability of employment we estimate a linear probability model. This makes the interpretation of the estimated coefficients easy and does not substantively change the conclusions when compared with results from a logit model. Following the labor economics literature, we transform wages by taking its natural logarithm. In our data, the distribution of logged wages is roughly normal. The two equations for labor market outcomes are therefore

$$
\begin{aligned}
\operatorname{Pr}\left(\mathrm{empl}_{i}\right) & =\alpha^{\mathrm{e}} \mathrm{BMI}_{i, \mathrm{LAG}}+\mathrm{Gen}_{i} \gamma^{\mathrm{e}}+X_{i} \beta^{\mathrm{e}}+\varepsilon_{i}^{\mathrm{e}} \\
\ln \left(w_{i}\right) & =\alpha^{\mathrm{w}} \mathrm{BMI}_{i, \mathrm{LAG}}+\mathrm{Gen}_{i} \gamma^{\mathrm{w}}+X_{i} \beta^{\mathrm{w}}+\varepsilon_{i}^{\mathrm{w}} \text { if employed }
\end{aligned}
$$


where $\mathrm{BMI}_{i, \mathrm{LAG}}$ is individual $i$ 's lagged $\mathrm{BMI}$, the vector Gen includes genetic information that affects wages directly, the vector $X$ includes exogenous explanatory variables, $\varepsilon$ is the i.i.d. error term, and the parameters to be estimated are $\alpha, \beta$, and $\gamma$. The superscripts e and $\mathrm{w}$ refer to employment and wages. The goal is to estimate consistent estimates of $\alpha^{\mathrm{e}}$ and $\alpha^{\mathrm{w}}$.

\subsection{Endogeneity}

The primary econometric concern is how to control for the endogeneity of BMI, our measure of obesity. There are two primary stories for why obesity is endogenous. Each explains a different way that employment or income affects obesity. Ruhm argues in a series of articles (e.g. Ruhm, 2000, 2003) that many individual health conditions are countercyclical with the macroeconomic conditions because unemployed persons have more time to exercise and eat well, and less income with which to purchase alcohol. Unemployed persons may also have more time to seek medical care. This reasoning implies that the estimated coefficient in a simple labor outcome regression is biased upwards.

Other stories suggest that the bias is downwards. Continuing first with Ruhm's macroeconomic example, employed adults are more likely to have health insurance than unemployed adults, which lowers the out-of-pocket cost and improves access to care. As for individual characteristics, lower discount rates makes a person invest more in all facets of human capital, creating a negative correlation between economic outcomes and obesity. Persons with low discount rates are more likely to invest in education, yielding higher average wages. They are also more likely to invest in health inputs, such as diet and exercise, which help to lower obesity. These explanations imply that the estimated coefficient in a simple labor outcome regression is biased downwards.

Given the concern about endogeneity bias, one way that we use genetic information to control for endogeneity is as instrumental variables. First, some genes provide natural experiments because they directly affect weight but not labor market outcomes. At conception some people are naturally predisposed to have a higher or lower BMI than other people. We estimate two-stage instrumental variable estimation, with multiple instruments that are correlated with obesity but unrelated to labor market outcomes. In our main models, the explanatory variable of interest, lagged BMI, is continuous. Because we estimate both main outcomes with ordinary least squares, we use two-stage least squares. The first-stage equation is

$$
\mathrm{BMI}_{i, \mathrm{LAG}}=\operatorname{GenIV}_{i} \theta+W \delta+\mathrm{Gen}_{i} \gamma^{\mathrm{BMI}}+X_{i} \beta^{\mathrm{BMI}}+v_{i}
$$

where GenIV is a vector of genetic information that are valid instruments, $W$ includes an additional valid instrument (siblings' lagged BMI), $v$ is the error term, and the other Greek letters are parameters to be estimated. In some specifications, we follow the prior literature and also include sibling's BMI as an instrumental variable.

Obesity is also endogenous if there are omitted variables related to both obesity and labor market outcomes. The most obvious examples of these are variables measuring satiation and gratification. Therefore, we also try to mitigate the omitted variable bias by including as many of these confounding variables as possible. Again we turn to genetic information. Some genetic information is correlated with both obesity and labor market outcomes. Such variables cannot be used as instruments but are included in both the main equation and the first-stage equation to predict lagged BMI.

Risky behaviors, such as smoking and drinking, may also reflect a low discount rate. We control for four self-reported risky behaviors in $X$ : ever smoked, like wild parties, drink alcohol or smoke marijuana, and like new experiences even if they are illegal, frightening, or unconventional. Each of these are plausibly correlated with both obesity and labor market outcomes, so omitting them would lead to further bias of the effect of obesity.

We try to address the endogeneity problem in part by using lagged BMI from the first or second waves of Add Health when respondents were in their late teens. Lagged BMI avoids the problem of 
reverse causality of employment and wages affecting BMI through diet and exercise. Averett and Korenman (1996) and Gortmaker et al. (1993) adopted a similar approach. BMI in late teens is primarily dependent on genes, diet from home (typically a mother's cooking), and exercise. All the instruments (genetics and lagged sibling BMI) predicted lagged BMI and other measures of obesity even better than current BMI for women and about the same for men. Many important decisions that affect future employment and wages are made during the late teens. These decisions include education and job sector.

Therefore, we used lagged BMI (or other measures of obesity) in all empirical models. The interpretation of the results is slightly different than in the prior literature. We estimate the effect of lagged BMI - when the respondents were in their late teens - on labor market outcomes when the respondents are in their mid-twenties.

\subsection{Other econometric issues}

We also estimated models in which continuous BMI is replaced by dummy variables indicating either that the person is overweight $(\mathrm{BMI} \geq 25)$ or obese $(\mathrm{BMI} \geq 30)$ to pick up nonlinear effects of BMI.

Another econometric issue is selection into the labor market. Although many studies of women's wages use Heckman selection models to estimate the unconditional effect of independent variables on wages, we do not. There are no plausible variables in Add Health that determine whether a woman works but are unrelated to her wages conditional on working. Models that have no such identifying variables rely solely on function form for identification and are notoriously unstable (Dow and Norton, 2003). Our results were quite unstable when identified soley through functional form. Therefore, we report a wage equation conditional on employment.

We control for heteroskedasticity and report robust standard errors for all models (Norton et al., 1996).

\section{DATA}

The National Longitudinal Study of Adolescent Health (Add Health) is a nationally representative study of how health-related behaviors in adolescents affect various outcomes in early adulthood. The first wave, which began in 1994, collected individual-, school-, and community-level information on respondents in grades 7-12. By Wave III, in 2001-2002, respondents were between 18 and 26 years old. We analyze data from the third wave on respondents at least age 21 because labor market outcomes are most relevant for these older respondents.

Among the 15197 participants in the Wave III of the Add Health data, DNA information was collected for 2574. The final sample of 769 women and 714 men was obtained among those 1344 women and 1230 men with DNA information after applying the following exclusion criteria:

1. not interviewed in Wave III (314 women and 291 men dropped);

2. younger than 21 years old ( 255 women, 196 men);

3. in active military service at the time of interview (6 women, 29 men).

\subsection{Dependent variables}

The probability of employment was estimated for the full sample. Persons were coded as employed if they reported working for pay for at least $10 \mathrm{~h}$ a week or were a student. Eighty-two percent of the 713 women and $88 \%$ of the 767 men were employed in the final sample, according to our definition (see Table I). The reference category includes both unemployed and discouraged workers.

The logarithm of wages was estimated for the sub-sample with positive wages. The Add Health data collected data on respondents' usual earnings excluding overtime pay, tips, and commissions at the current job. The unit of collected earnings varies from hourly to yearly. We converted all the reported 
Table I. Summary statistics of non-genetic variables, Add Health data, Wave III

\begin{tabular}{|c|c|c|c|c|}
\hline \multirow[b]{2}{*}{ Variables } & \multicolumn{4}{|c|}{ Means } \\
\hline & Women & Men & Min. & Max. \\
\hline \multicolumn{5}{|l|}{ Dependent variables } \\
\hline Employed & 0.82 & 0.88 & 0 & 1 \\
\hline $\ln$ (wages) $(N=524 ; 540)$ & 2.18 & 2.23 & 0 & 3.76 \\
\hline Wages $(\$)(N=524 ; 540)$ & 10.54 & 11.09 & 1 & 43 \\
\hline \multicolumn{5}{|l|}{ Variable of interest } \\
\hline BMI, lagged & 22.79 & 23.62 & 14.61 & 47.35 \\
\hline \multicolumn{5}{|l|}{ Sibling data } \\
\hline Siblings' BMI, lagged & 24.30 & 24.703 & 14.61 & 47.35 \\
\hline \multicolumn{5}{|l|}{ Demographic variables } \\
\hline Age -20 & 2.610 & 2.669 & 1 & 6 \\
\hline African American & 0.162 & 0.141 & 0 & 1 \\
\hline Hispanic & 0.148 & 0.169 & 0 & 1 \\
\hline Married & 0.256 & 0.150 & 0 & 1 \\
\hline \multicolumn{5}{|l|}{ Education } \\
\hline$>$ High school & 0.618 & 0.556 & 0 & 1 \\
\hline Attending school & 0.369 & 0.328 & 0 & 1 \\
\hline \multicolumn{5}{|l|}{ Perceived health status } \\
\hline Excellent or very good & 0.727 & 0.762 & 0 & 1 \\
\hline Measured height (m) & 1.629 & 1.775 & 1.22 & 2.13 \\
\hline \multicolumn{5}{|l|}{ Risky behaviors } \\
\hline Ever smoked & 0.343 & 0.451 & 0 & 1 \\
\hline Like wild parties & 0.238 & 0.370 & 0 & 1 \\
\hline Drink, smoke marijuana & 0.321 & 0.550 & 0 & 1 \\
\hline Like new experiences & 0.328 & 0.561 & 0 & 1 \\
\hline \multicolumn{5}{|l|}{ Regional variables } \\
\hline West & 0.228 & 0.249 & 0 & 1 \\
\hline Midwest & 0.342 & 0.325 & 0 & 1 \\
\hline South & 0.329 & 0.329 & 0 & 1 \\
\hline$N$ & 769 & 714 & 1483 & 1483 \\
\hline
\end{tabular}

earnings to an hourly basis. On average, women (\$10.54) who worked earned slightly less per hour than men (\$11.09). Hourly wages increased with age in the employed sample.

\subsection{BMI}

The explanatory variable of primary interest is lagged BMI. BMI is weight in kilograms divided by height in meters squared. We used measured - not self-reported - height and weight because of the known biases in self-reported data. Lagged BMI was defined as BMI at Wave I for sample persons aged $>24$ years old at Wave III, and BMI at Wave II for sample aged $<25$ year old at Wave III. In our final sample, lagged BMI ranges from 15 to 42 for women (mean of 22.8) and 15 to 47 for men (mean of 23.6). Less than a quarter of the overall sample is overweight or obese ( $22 \%$ for women and for $29 \%$ for men). Average lagged BMI increases with age. The average height of women is five feet four inches; for men it is five feet eight inches.

\subsection{Other control variables}

Age ranges from 21 to 26, by construction, in our sample, with an average age of 22.6 years. About $15 \%$ of the sample was non-Hispanic Black and another $16 \%$ were Hispanic. One-fifth of the women are married, but only $15.5 \%$ of the men are married. Nearly two-thirds of women have a college education or higher, while only $54 \%$ of men do. The vast majority of the sample report being in excellent or very 
good health status. About $10 \%$ live in the Northeast, while the other three regional areas were represented fairly evenly.

\subsection{Instruments and specification tests}

All the genetic variables were based on whether either of the two alleles for each gene had a specific genotype. A value of one indicates that either one of the alleles (or both) showed a specific polymorphism. Because multiple polymorphisms of one gene may be related to obesity, we sometimes created more than one variable per gene. The genetic instruments come from two of the genes (see Table II). The 48-bp repeat polymorphism of the Dopamine D4 Receptor (DRD4 gene) and the Dopamine Transporter (DAT1 gene) are instruments for BMI. Specifically, for women we construct two instruments: the 379 frequency (or genotype) in allele A and other frequencies in allele B in the

Table II. Summary statistics of genetic variables, Add Health data, Wave III

\begin{tabular}{|c|c|c|c|c|}
\hline & \multicolumn{2}{|c|}{ Means } & \multicolumn{2}{|c|}{ Coefficients } \\
\hline & Women & Men & Women & Men \\
\hline \multicolumn{5}{|l|}{ Genetic variables used as IVs } \\
\hline \multicolumn{5}{|l|}{ DRD4: Dopamine D4 Receptor } \\
\hline $\begin{array}{l}\text { DRD4_379_other } \\
\text { Allele A has } 379 \text { frequency, B has other }\end{array}$ & 0.134 & & $-1.85^{* *}$ & \\
\hline $\begin{array}{l}\text { DRD4_427either } \\
\text { Either Allele } A \text { or B has } 427 \text { frequency }\end{array}$ & 0.048 & & $-2.09^{* *}$ & \\
\hline $\begin{array}{l}\text { DRD4_other_427 } \\
\text { Allele A has other, B has } 427 \text { frequency }\end{array}$ & & 0.010 & & $-3.76^{* *}$ \\
\hline $\begin{array}{l}\text { DRD4_427_427 } \\
\text { Both alleles have } 427 \text { frequency }\end{array}$ & & 0.003 & & $-2.16^{* *}$ \\
\hline \multicolumn{5}{|l|}{ DAT1: Dopamine Transporter } \\
\hline $\begin{array}{l}\text { DAT1_440either } \\
\text { Either Allele A or B has } 440 \text { frequency }\end{array}$ & & 0.385 & & -0.78 \\
\hline \multicolumn{5}{|l|}{ Genetic variables used as controls } \\
\hline $\begin{array}{l}\text { SLC_484_other } \\
\text { Allele A has } 484 \text { frequency, } B \text { has other }\end{array}$ & 0.915 & 0.917 & -0.05 & 0.33 \\
\hline $\begin{array}{l}\text { SLC_484_484 } \\
\text { Both alleles have } 484 \text { frequency }\end{array}$ & 0.196 & 0.213 & 0.14 & 0.49 \\
\hline \multicolumn{5}{|l|}{ DRD2: Dopamine D2 Receptor TaqIA } \\
\hline $\begin{array}{l}\text { DRD2_178either } \\
\text { Either Allele A or B has } 178 \text { frequency }\end{array}$ & 0.915 & 0.917 & 0.14 & -0.77 \\
\hline $\begin{array}{l}\text { DRD2_304either } \\
\text { Either Allele A or B has } 304 \text { frequency }\end{array}$ & 0.489 & 0.465 & 0.84 & -0.39 \\
\hline \multicolumn{5}{|l|}{ MAOA: Monoamine oxidase A-uVNTR } \\
\hline $\begin{array}{l}\text { MAOA_351_other } \\
\text { Allele } A \text { has } 351 \text { frequency, B has other }\end{array}$ & 0.017 & & 0.003 & \\
\hline $\begin{array}{l}\text { MAOA_other_351 } \\
\text { Allele } \bar{A} \text { has other, B has } 351 \text { frequency }\end{array}$ & 0.471 & & 0.13 & \\
\hline $\begin{array}{l}\text { MAOA_351_351 } \\
\text { Both alleles have } 351 \text { frequency }\end{array}$ & 0.334 & & -0.02 & \\
\hline $\begin{array}{l}\text { MAOA_321either } \\
\text { Either_Allele A or B has } 321 \text { frequency }\end{array}$ & & 0.622 & & 0.58 \\
\hline $\begin{array}{l}\text { MAOA_351either } \\
\text { Either Allele A or B has } 351 \text { frequency }\end{array}$ & & 0.822 & & -0.50 \\
\hline $\begin{array}{l}\text { CYP: Cytochrome P450 2A6 } \\
\text { CYP_leither } \\
\text { Either Allele A or B has } 1 \text { frequency }\end{array}$ & 0.957 & 0.948 & -2.16 & $-2.08^{*}$ \\
\hline$N$ & 769 & 714 & 769 & 714 \\
\hline
\end{tabular}

The coefficients reported in the last two columns are from 20 simple regressions of lagged BMI on the genetic dummy variable and a constant term. Robust standard errors are in parentheses. $p$-value $<0.01^{* *},<0.05^{*}$. 
DRD4 gene; and the 427 frequency in either allele A or allele B in the DRD4 gene. Empirically, a different set of genes worked well as instruments for men, according to the specification tests. For men, we construct three slightly different instruments: the 427 frequency in allele B and other frequencies in allele A in the DRD4 gene; the 427 frequency in both alleles A and B in the DRD4 gene; and the 440 frequency in either allele A or allele B in the DAT1 gene.

One way to show that the genetic variables predict lagged BMI is to calculate the difference in mean lagged BMI by genotype. We ran 20 simple regressions of lagged BMI on the genetic dummy variables and a constant term (see columns 3 and 4 of Table II). Four of the five genetic instruments have coefficients that are large in magnitude and statistically significant at the $1 \%$ level. For example, the second number in the third column (-2.09) indicates that if either allele A or B of dopamine D4 receptor is 427 frequency, then the woman will be two units lower in BMI, on average.

The siblings' lagged BMI averaged 24.3, just like for the study sample, and had similar range. The correlation coefficient between lagged BMI and siblings' lagged BMI is 0.377 . Nearly $20 \%$ of the sample did not report a BMI for any sibling, possibly because they have no sibling. For those sample that have missing data for siblings' BMI, we filled it with average siblings' BMI.

Specification tests confirm that our instruments are strong for women and validly excluded from the main equations for men and women. The genetic instrumental variables are jointly statistically significant at the $1 \%$ level in both first-stage regressions for women, with $F$-statistics of 10.07 and 7.10 (see first column in top panel of Table III). The full set of instruments (also including lagged siblings' BMI) have even higher explanatory power in the first-stage regression - the $F$-statistics are 14.83 and 18.38, which exceed the minimum of 10 suggested by Staiger and Stock (1997). These results confirm that for women, the genetic variables are good instruments for BMI, especially when also including lagged siblings' BMI. However, for men even though the instruments are jointly statistically significant at the $1 \%$ level, the $F$-statistics are only between 4 and 5 (see first column of bottom panel of Table III).

Table III. Specification tests of the instrumental variables

\begin{tabular}{|c|c|c|c|c|c|}
\hline \multirow[b]{2}{*}{ Dependent variable } & \multirow[b]{2}{*}{$N$} & \multicolumn{3}{|c|}{ Specification tests } & \multirow[b]{2}{*}{ Conclusions } \\
\hline & & IV Strength & Over-id $p$-value & Exogeneity $p$-value & \\
\hline \multicolumn{6}{|l|}{ Women } \\
\hline \multicolumn{6}{|c|}{ IVs: two genetic variables } \\
\hline $\operatorname{Pr}($ employed $)$ & 769 & $\begin{array}{l}F=10.07 \\
p=0.0001\end{array}$ & 0.223 & 0.893 & Good IVs, exogenous \\
\hline $\ln$ (wages) & 524 & $\begin{array}{l}F=7.10 \\
p=0.0014\end{array}$ & 0.590 & 0.612 & Weak IVs, exogenous \\
\hline \multicolumn{6}{|c|}{ IVs: two genetic variable and lagged sibling BMI } \\
\hline $\operatorname{Pr}($ employed) & 769 & $\begin{array}{l}F=14.83 \\
p<0.0001\end{array}$ & 0.450 & 0.828 & Good IVs, exogenous \\
\hline $\ln$ (wages) & 524 & $\begin{array}{l}F=18.38 \\
p<0.0001\end{array}$ & 0.808 & 0.638 & Good IVs, exogenous \\
\hline \multicolumn{5}{|c|}{ IVs: three genetic variables } & \\
\hline $\operatorname{Pr}($ employed $)$ & 714 & $\begin{array}{l}F=4.43 \\
p=0.0057\end{array}$ & 0.415 & 0.682 & Weak IVs, exogenous \\
\hline $\ln$ (wages) & 540 & $\begin{array}{l}F=4.12 \\
p=0.0085\end{array}$ & 0.865 & 0.716 & Weak IVs, exogenous \\
\hline \multicolumn{6}{|c|}{ IVs: three genetic variable and lagged sibling $B M I$} \\
\hline $\operatorname{Pr}($ employed $)$ & 714 & $\begin{array}{l}F=4.98 \\
p=0.0010\end{array}$ & 0.471 & 0.253 & Weak IVs, exogenous \\
\hline $\ln$ (wages) & 540 & $\begin{array}{l}F=4.25 \\
p=0.0032\end{array}$ & 0.844 & 0.893 & Weak IVs, exogenous \\
\hline
\end{tabular}

The null hypothesis that the over-identifying instruments are excluded from the main equations was tested using an LM test. The null hypothesis that BMI is exogenous was tested using an $N R^{2}$ test. 
The marginal increase in $R^{2}$ by adding the instruments was 0.089 for women and 0.148 for men, after controlling for the other exogenous variables. Because the instrumental variables are not strong in all models, we also report single-stage regressions, with and without controlling for genetic information, to show how the results vary with different specifications.

Siblings' lagged BMI also does well on its own (results not reported); this is not surprising given its use as an instrument for obesity in the published literature.

Regression-based Hausman tests did not reject the null hypothesis of the exogeneity of lagged BMI at the 5\% level for employment and for wages, for both genders (see Table III). LM tests of the exclusion restrictions did not reject the null hypothesis for both labor market outcomes for both genders (see Table III).

The variable most often used in the prior obesity-labor market literature as an instrument was sibling's BMI. Because it was used by itself, justification was theoretical but not empirical. Prior researchers could not conduct the over-id test of whether the instruments could be excluded from the main equation. Having multiple genetic variables in our data set allows us to then test the hypothesis that lagged sibling's BMI is a valid instrument. It is, see the lower half of each panel of Table III for the specification test results. Including lagged sibling's BMI greatly improves the strength of the combined instruments in the first stage, at least for women. These specification tests are important on their own because they help justify the choice of instrumental variable used in the prior literature, using a test not previously available.

Through the process of subjecting variables to the specification tests, we also found genetic variables that both predicted BMI and failed the over-identification test. We created dummy variables based on frequencies in either or both alleles of four different genes (see Table II for details). These variables are included in both the first stage and the main equations to help control for omitted variable bias.

\subsection{Robustness checks}

We tried numerous other specifications to test the robustness of the results. For example, we tried various combinations of instruments. The 2SLS results that include lagged sibling's BMI are not substantially different than results with just the genetic information (results not reported). We also ran just-identified 2SLS models with either just the genetic variables or just the siblings' BMI (results not reported). The estimated effect of BMI remains stable and small across different sets of instruments. We also tried different definitions of employment before settling on at least 10 hours per week. For example, we tried raising the minimum number of hours to $20-40$, and also tried excluding students. None of these definitions produced substantially different results.

To test for a possible nonlinear effect of BMI, we tried categorizing BMI into normal weight, overweight, and obese instead of using a continuous measure. For women, the instruments predict being either overweight or being obese well for the full sample, but for the subset of employed women, the instruments are weak. The effects of the categorical measures of obesity on labor market outcomes are statistically insignificant. We also estimated models with three linear splines. We have tried excluding variables such as education and marital status that are arguably endogenous too. None of these changes altered the results substantively. Finally, we ran instrumental variable probit models and found the partial effects to be comparable to linear probability model coefficients.

\section{RESULTS}

The first-stage regression results provide further evidence that the instrumental variables are substantively negatively related to obesity, as measured by BMI (see Table IV). When using only genetic variables as instruments, the estimated coefficients are -1.27 and -2.36 for women, and $-0.90,-2.09$, and -3.12 for men. When lagged sibling's BMI is added, the magnitudes of the 
Table IV. First-stage regression results to predict lagged BMI for women and men

\begin{tabular}{|c|c|c|c|c|}
\hline \multirow[b]{2}{*}{ Variables } & \multicolumn{2}{|c|}{ Women } & \multicolumn{2}{|c|}{ Men } \\
\hline & BMI (lagged) & BMI (lagged) & BMI (lagged) & BMI (lagged) \\
\hline Constant & $\begin{array}{c}9.95 \\
(6.23)\end{array}$ & $\begin{array}{c}4.19 \\
(6.90)\end{array}$ & $\begin{array}{c}25.28^{* *} \\
(6.55)\end{array}$ & $\begin{array}{r}15.78^{*} \\
(6.91)\end{array}$ \\
\hline \multicolumn{5}{|l|}{ Instrumental variables } \\
\hline DRD4_379_other & $\begin{array}{c}-1.27^{* *} \\
(0.46)\end{array}$ & $\begin{array}{l}-0.85 \\
(0.59)\end{array}$ & & \\
\hline DRD4_427either & $\begin{array}{c}-2.36^{* *} \\
(0.80)\end{array}$ & $\begin{array}{c}-1.93^{*} \\
(0.84)\end{array}$ & & \\
\hline DAT1_440either & & & $\begin{array}{l}-0.90 \\
(0.52)\end{array}$ & $\begin{array}{r}-1.01^{*} \\
(0.48)\end{array}$ \\
\hline DRD4_427_427 & & & $\begin{array}{l}-2.09 \\
(1.09)\end{array}$ & $\begin{array}{c}-5.41^{* *} \\
(1.26)\end{array}$ \\
\hline DRD4_other_427 & & & $\begin{array}{c}-3.12^{* *} \\
(1.18)\end{array}$ & $\begin{array}{c}-2.60^{* *} \\
(1.00)\end{array}$ \\
\hline Sibling BMI (lagged) & & $\begin{array}{c}0.407^{* *} \\
(0.072)\end{array}$ & & $\begin{array}{r}0.449^{* *} \\
(0.084)\end{array}$ \\
\hline \multicolumn{5}{|l|}{ Genetic controls } \\
\hline SLC_484_other & $\begin{array}{c}0.38 \\
(0.50)\end{array}$ & $\begin{array}{l}-0.37 \\
(0.62)\end{array}$ & $\begin{array}{c}0.56 \\
(0.58)\end{array}$ & $\begin{array}{c}0.19 \\
(0.55)\end{array}$ \\
\hline SLC_484_484 & $\begin{array}{c}0.74 \\
(0.69)\end{array}$ & $\begin{array}{l}-0.33 \\
(0.77)\end{array}$ & $\begin{array}{c}0.70 \\
(0.79)\end{array}$ & $\begin{array}{c}0.44 \\
(0.71)\end{array}$ \\
\hline DRD2_178either & $\begin{array}{c}0.58 \\
(0.90)\end{array}$ & $\begin{array}{l}1.38 \\
(0.90)\end{array}$ & $\begin{array}{l}-1.21 \\
(0.87)\end{array}$ & $\begin{array}{l}-1.54 \\
(0.89)\end{array}$ \\
\hline DRD2_304either & $\begin{array}{c}0.70 \\
(0.52)\end{array}$ & $\begin{array}{c}0.77 \\
(0.59)\end{array}$ & $\begin{array}{l}-0.20 \\
(0.53)\end{array}$ & $\begin{array}{l}-0.33 \\
(0.51)\end{array}$ \\
\hline MAOA_351_other & $\begin{array}{c}0.43 \\
(1.34)\end{array}$ & $\begin{array}{l}-1.44 \\
(1.46)\end{array}$ & & \\
\hline MAOA_other_351 & $\begin{array}{c}0.18 \\
(0.62)\end{array}$ & $\begin{array}{l}1.09 \\
(0.71)\end{array}$ & & \\
\hline MAOA_351_351 & $\begin{array}{c}0.17 \\
(0.69)\end{array}$ & $\begin{array}{c}0.53 \\
(0.82)\end{array}$ & & \\
\hline MAOA_321either & & & $\begin{array}{c}1.02 \\
(1.33)\end{array}$ & $\begin{array}{l}1.50 \\
(0.90)\end{array}$ \\
\hline MAOA_351either & & & $\begin{array}{c}0.31 \\
(1.33)\end{array}$ & $\begin{array}{l}1.00 \\
(0.89)\end{array}$ \\
\hline CYP_1either & $\begin{array}{l}-1.83 \\
(1.03)\end{array}$ & $\begin{array}{l}-1.99 \\
(1.26)\end{array}$ & $\begin{array}{l}-1.83 \\
(1.16)\end{array}$ & $\begin{array}{l}-1.84 \\
(1.21)\end{array}$ \\
\hline \multicolumn{5}{|l|}{ Demographics } \\
\hline Age -20 & $\begin{array}{c}0.20 \\
(0.20)\end{array}$ & $\begin{array}{c}0.31 \\
(0.22)\end{array}$ & $\begin{array}{c}0.17 \\
(0.19)\end{array}$ & $\begin{array}{c}0.27 \\
(0.19)\end{array}$ \\
\hline African American & $\begin{array}{l}2.50^{* *} \\
(0.96)\end{array}$ & $\begin{array}{l}3.39^{*} \\
(1.54)\end{array}$ & $\begin{array}{l}-1.46^{*} \\
(0.64)\end{array}$ & $\begin{array}{l}-1.10 \\
(0.61)\end{array}$ \\
\hline Hispanic & $\begin{array}{l}2.16^{*} \\
(0.86)\end{array}$ & $\begin{array}{l}1.92 \\
(1.07)\end{array}$ & $\begin{array}{c}0.29 \\
(0.76)\end{array}$ & $\begin{array}{c}0.31 \\
(0.79)\end{array}$ \\
\hline Married & $\begin{array}{l}-0.68 \\
(0.60)\end{array}$ & $\begin{array}{l}-0.65 \\
(0.68)\end{array}$ & $\begin{array}{c}0.21 \\
(0.72)\end{array}$ & $\begin{array}{c}0.48 \\
(0.71)\end{array}$ \\
\hline \multicolumn{5}{|l|}{ Education } \\
\hline$>$ High school & $\begin{array}{c}0.14 \\
(0.55)\end{array}$ & $\begin{array}{l}-0.41 \\
(0.62)\end{array}$ & $\begin{array}{c}0.51 \\
(0.61)\end{array}$ & $\begin{array}{c}0.52 \\
(0.58)\end{array}$ \\
\hline Attending school & $\begin{array}{c}-1.27^{* * *} \\
(0.49)\end{array}$ & $\begin{array}{c}-1.35^{*} \\
(0.54)\end{array}$ & $\begin{array}{l}-0.81 \\
(0.63)\end{array}$ & $\begin{array}{l}-0.41 \\
(0.60)\end{array}$ \\
\hline$R^{2}$ & 0.154 & 0.286 & 0.106 & 0.241 \\
\hline$N$ & 769 & 769 & 714 & 714 \\
\hline
\end{tabular}

Robust standard errors are in parentheses. $p$-value $<0.01^{* *},<0.05^{*}$. Regressions also include two health status variables, four risky behavior variables, and three regional dummy variables.

genetic coefficients remain large and negative. To put the magnitudes in perspective, a one-unit increase in BMI for a six-foot tall person corresponds to an increase of 7.3 pounds. For a five-foot person a oneunit increase in BMI corresponds to an increase of over five pounds. Therefore, genetic variation alone 
leads to considerable exogenous changes in weight for a person of average height. A change in certain genes leads to exogenous reductions in weight of at least 5 pounds for most people and for some more than 20 pounds. These coefficients are of meaningful magnitude, even after controlling for other covariates. In addition, lagged siblings' BMI is strongly statistically significant for both men and women, with coefficients greater than 0.4. The $R^{2}$ values are 0.286 for women and 0.241 for men. As a robustness check, the genetic instrumental variables also strongly predict the probability of being overweight or obese, at least for women (results not reported). In sum, the instruments are strongly related to lagged BMI in the first-stage regression. We report two-stage least squares results using the full set of instruments, including lagged siblings' BMI, but show in Table IV the strength of the genetic variables on their own.

As a further check, we ran simple regressions of lagged BMI on each instrument and genetic variable by itself (with a constant) to show that simple correlations are both statistically strong and high in magnitude (see the third and fourth columns of Table II). Four of the five coefficients are greater than 1.85 in absolute value and statistically significant at the $1 \%$ level. Furthermore, adding the other exogenous covariates, but not the other instruments, does not change the simple correlation much (results not reported). Therefore, the large magnitudes found in the first-stage regression are not due to multicollinearity or other statistical problems.

Several other coefficients in the first-stage results have signs that are consistent with the literature and are statistically significant. Higher lagged BMI is found for African American and Hispanic women, taller women, and women not attending school. African-American men have lower BMI on average. These additional results are reassuring. Like the rest of the obesity literature, our results showed that lagged BMI is positively correlated with being older, unmarried, and in poor selfreported health, although those estimated coefficients are mostly not statistically significant at conventional levels.

The main results show that lagged BMI has essentially no effect on labor market outcomes for women (see Table V). Six different models control for genetic information and endogeneity in different ways. In a least square regression with no controls for genetic information, lagged BMI has no effect on the probability of employment (see the first column of Table V). In a richer model controlling for exogenous genetic information, the coefficient on lagged BMI stays at about the same magnitude and remains statistically insignificant. This may be because the extent of omitted variable bias is small. Adding covariates raises the $R^{2}$ to nearly 0.200 . The 2 SLS results are smaller in magnitude, but again are not statistically significant (see the third column of Table V).

Coefficients on other variables have the expected signs. The probability of employment is higher for women who are older, white, unmarried, and with higher education.

The overall results for the wage equation for women are not statistically significant (see Table V). In the log wage equation, a higher lagged BMI has no statistically significant effect on wages in any of the models. The $R^{2}$ in regressions with genetic covariates is 0.185 . As with the probability of employment, the 2SLS estimates were more negative than the single equation results. To the extent that controlling for endogeneity lowered the estimated coefficient on lagged BMI, previous studies may have been biased.

For men, lagged BMI is not statistically significant in any of the labor market outcome models (see Table VI). The coefficients on lagged BMI are small in magnitude and insignificant in linear regressions, and somewhat larger but still insignificant in 2SLS. The $R^{2}$ values range from 0.111 to 0.177 . For $\log$ wages, the single equation results show lagged BMI to be positively related to log wages (although not significant). The 2 SLS results shrink the coefficient nearly to zero; because the first-stage $F$-statistic was less than 10 , the single-equation results are preferred.

Although the coefficients on lagged BMI are not statistically significant, the standard errors are generally quite tight (even in the 2SLS models). Therefore, we can rule out large effects. For women, the 
Table V. Linear probability models of employment and log wages for women

\begin{tabular}{|c|c|c|c|c|c|c|}
\hline \multirow[b]{2}{*}{ Variables } & \multicolumn{3}{|c|}{ Employment } & \multicolumn{3}{|c|}{$\ln$ (Wages) } \\
\hline & LPM & LPM & 2SLS & LPM & LPM & 2SLS \\
\hline Constant & $\begin{array}{l}0.56 \\
(0.42)\end{array}$ & $\begin{array}{l}0.72 \\
(0.42)\end{array}$ & $\begin{array}{l}0.74 \\
(0.44)\end{array}$ & $\begin{array}{l}1.74^{* *} \\
(0.53)\end{array}$ & $\begin{array}{l}1.19^{*} \\
(0.56)\end{array}$ & $\begin{array}{l}1.32^{*} \\
(0.60)\end{array}$ \\
\hline BMI (lagged) & $\begin{array}{l}0.0049 \\
(0.0036)\end{array}$ & $\begin{array}{l}0.0043 \\
(0.0033)\end{array}$ & $\begin{array}{l}0.002 \\
(0.011)\end{array}$ & $\begin{array}{l}0.0014 \\
(0.0052)\end{array}$ & $\begin{array}{l}0.0046 \\
(0.0046)\end{array}$ & $\begin{array}{l}-0.005 \\
(0.021)\end{array}$ \\
\hline $\begin{array}{l}\text { Genetic controls } \\
\text { Demographics }\end{array}$ & & 8 vars. & 8 vars. & & 8 vars. & 8 vars. \\
\hline Age -20 & $\begin{array}{l}0.018 \\
(0.011)\end{array}$ & $\begin{array}{l}0.018 \\
(0.012)\end{array}$ & $\begin{array}{l}0.019 \\
(0.012)\end{array}$ & $\begin{array}{l}0.105^{* *} \\
(0.023)\end{array}$ & $\begin{array}{l}0.103^{* *} \\
(0.023)\end{array}$ & $\begin{array}{l}0.105^{* *} \\
(0.024)\end{array}$ \\
\hline African American & $\begin{array}{l}-0.121^{*} \\
(0.057)\end{array}$ & $\begin{array}{l}-0.124^{*} \\
(0.056)\end{array}$ & $\begin{array}{l}-0.118 \\
(0.070)\end{array}$ & $\begin{array}{l}-0.24 \\
(0.15)\end{array}$ & $\begin{array}{l}-0.30^{*} \\
(0.14)\end{array}$ & $\begin{array}{l}-0.26 \\
(0.17)\end{array}$ \\
\hline Hispanic & $\begin{array}{l}0.0071 \\
(0.046)\end{array}$ & $\begin{array}{l}0.012 \\
(0.045)\end{array}$ & $\begin{array}{l}0.018 \\
(0.052)\end{array}$ & $\begin{array}{l}0.030 \\
(0.10)\end{array}$ & $\begin{array}{l}-0.032 \\
(0.10)\end{array}$ & $\begin{array}{l}-0.004 \\
(0.10)\end{array}$ \\
\hline Married & $\begin{array}{l}-0.025 \\
(0.041)\end{array}$ & $\begin{array}{l}-0.014 \\
(0.046)\end{array}$ & $\begin{array}{l}-0.015 \\
(0.046)\end{array}$ & $\begin{array}{l}0.097^{*} \\
(0.042)\end{array}$ & $\begin{array}{l}0.088 \\
(0.049)\end{array}$ & $\begin{array}{l}0.079 \\
(0.045)\end{array}$ \\
\hline Education & & & & & & \\
\hline$>$ High school & $\begin{array}{l}0.177^{* *} \\
(0.048)\end{array}$ & $\begin{array}{l}0.176^{* *} \\
(0.047)\end{array}$ & $\begin{array}{l}0.177^{* *} \\
(0.049)\end{array}$ & $\begin{array}{l}0.0098 \\
(0.061)\end{array}$ & $\begin{array}{l}0.0069 \\
(0.057)\end{array}$ & $\begin{array}{l}0.005 \\
(0.057)\end{array}$ \\
\hline Attending school & $\begin{array}{l}0.207^{* *} \\
(0.028)\end{array}$ & $\begin{array}{l}0.209^{* *} \\
(0.027)\end{array}$ & $\begin{array}{l}0.206^{* *} \\
(0.028)\end{array}$ & $\begin{array}{l}-0.041 \\
(0.070)\end{array}$ & $\begin{array}{l}-0.075 \\
(0.069)\end{array}$ & $\begin{array}{l}-0.091 \\
(0.083)\end{array}$ \\
\hline$R^{2}$ & 0.182 & 0.196 & 0.195 & 0.136 & 0.185 & 0.180 \\
\hline$N$ & 769 & 769 & 769 & 524 & 524 & 524 \\
\hline
\end{tabular}

Robust standard errors are in parentheses. $p$-value $<0.01^{* *},<0.05^{*}$. All regressions also include two health status variables, four risky behavior variables, and three regional dummy variables. The 2SLS models use two genetic variables and lagged sibling BMI as instrumental variables.

Table VI. Linear probability models of employment and log wages for men

\begin{tabular}{|c|c|c|c|c|c|c|}
\hline \multirow[b]{2}{*}{ Variables } & \multicolumn{3}{|c|}{ Employment } & \multicolumn{3}{|c|}{$\ln$ (Wages) } \\
\hline & LPM & LPM & 2SLS & LPM & LPM & 2SLS \\
\hline Constant & $\begin{array}{l}0.56 \\
(0.35)\end{array}$ & $\begin{array}{l}0.64^{*} \\
(0.32)\end{array}$ & $\begin{array}{l}0.44 \\
(0.38)\end{array}$ & $\begin{array}{l}1.55^{*} \\
(0.75)\end{array}$ & $\begin{array}{l}1.15 \\
(1.05)\end{array}$ & $\begin{array}{l}1.17 \\
(1.09)\end{array}$ \\
\hline BMI (lagged) & $\begin{array}{l}0.0006 \\
(0.0031)\end{array}$ & $\begin{array}{l}-0.0009 \\
(0.0030)\end{array}$ & $\begin{array}{l}0.0071 \\
(0.0049)\end{array}$ & $\begin{array}{l}0.0008 \\
(0.0048)\end{array}$ & $\begin{array}{l}0.0012 \\
(0.0045)\end{array}$ & $\begin{array}{l}0.0001 \\
(0.0092)\end{array}$ \\
\hline $\begin{array}{l}\text { Genetic controls } \\
\text { Demographics }\end{array}$ & & 7 vars. & 7 vars. & & 7 vars. & 7 vars. \\
\hline Age -20 & $\begin{array}{l}-0.013 \\
(0.015)\end{array}$ & $\begin{array}{l}-0.013 \\
(0.014)\end{array}$ & $\begin{array}{l}-0.015 \\
(0.014)\end{array}$ & $\begin{array}{l}0.028 \\
(0.022)\end{array}$ & $\begin{array}{l}0.033 \\
(0.022)\end{array}$ & $\begin{array}{l}0.033 \\
(0.022)\end{array}$ \\
\hline African American & $\begin{array}{l}-0.161^{* *} \\
(0.061)\end{array}$ & $\begin{array}{l}-0.172^{*} \\
(0.061)\end{array}$ & $\begin{array}{l}-0.162^{*} \\
(0.063)\end{array}$ & $\begin{array}{l}-0.0046 \\
(0.090)\end{array}$ & $\begin{array}{l}-0.035 \\
(0.097)\end{array}$ & $\begin{array}{l}-0.036 \\
(0.098)\end{array}$ \\
\hline Hispanic & $\begin{array}{l}-0.0056 \\
(0.051)\end{array}$ & $\begin{array}{l}-0.029 \\
(0.051)\end{array}$ & $\begin{array}{l}-0.031 \\
(0.051)\end{array}$ & $\begin{array}{l}-0.041 \\
(0.13)\end{array}$ & $\begin{array}{l}-0.064 \\
(0.13)\end{array}$ & $\begin{array}{l}-0.06 \\
(0.13)\end{array}$ \\
\hline Married & $\begin{array}{l}0.120^{* *} \\
(0.031)\end{array}$ & $\begin{array}{l}0.113^{* *} \\
(0.028)\end{array}$ & $\begin{array}{l}0.111^{* *} \\
(0.029)\end{array}$ & $\begin{array}{l}0.241^{* *} \\
(0.060)\end{array}$ & $\begin{array}{l}0.224^{* *} \\
(0.057)\end{array}$ & $\begin{array}{l}0.224^{* *} \\
(0.057)\end{array}$ \\
\hline Education & & & & & & \\
\hline$>$ High school & $\begin{array}{l}0.111^{*} \\
(0.049)\end{array}$ & $\begin{array}{l}0.114^{*} \\
(0.047)\end{array}$ & $\begin{array}{l}0.109^{*} \\
(0.049)\end{array}$ & $\begin{array}{l}0.088 \\
(0.053)\end{array}$ & $\begin{array}{l}0.10 \\
(0.053)\end{array}$ & $\begin{array}{l}0.102 \\
(0.054)\end{array}$ \\
\hline Attending school & $\begin{array}{l}0.101^{* *} \\
(0.028)\end{array}$ & $\begin{array}{l}0.101^{* *} \\
(0.028)\end{array}$ & $\begin{array}{l}0.108^{* *} \\
(0.026)\end{array}$ & $\begin{array}{l}-0.280^{* *} \\
(0.067)\end{array}$ & $\begin{array}{l}-0.274^{* *} \\
(0.068)\end{array}$ & $\begin{array}{l}-0.275^{* *} \\
(0.069)\end{array}$ \\
\hline$R^{2}$ & 0.143 & 0.177 & 0.162 & 0.111 & 0.140 & 0.140 \\
\hline$N$ & 714 & 714 & 714 & 540 & 540 & 540 \\
\hline
\end{tabular}

Robust standard errors are in parentheses. $p$-value $<0.01^{* *},<0.05^{*}$. Regressions also include two health status variables, four risky behavior variables, and three regional dummy variables. The 2SLS models use three genetic variables and lagged sibling BMI as instrumental variables. 
effect of a one-unit increase in lagged BMI is unlikely to be as large as one percentage point for employment or $1 \%$ in wages.

\section{CONCLUSION}

Our study has one policy conclusion and two methodological contributions. Limitations include the relatively small sample size (although prior economic studies have had roughly the same sample size) and a focus on labor market outcomes restricted to persons in their mid-twenties. The policy conclusion is that an increase in BMI as a late teen has no statistically significant effect on either employment or wages for a person in their mid-twenties. Our study is by no means the first to find no significant effect of obesity measures on labor market outcome. Our study is better able to combat the endogeneity of obesity in several ways - through the use of lagged BMI, actual (not self-reported) BMI, additional controls for previously omitted genetic information, and strong instrumental variables. Our findings, while a null finding, are important because of the rise in obesity in the United States and the concern about the effect of obesity on labor market outcomes.

The main methodological contribution is the novel use of genetic information, both as instrumental variables and as extra exogenous variables to reduce omitted variable bias. We demonstrated that genetic information is highly predictive of lagged BMI and the probability of being overweight or obese. The relationship is strong in both magnitude and statistical significance. This is the first published social science paper that we know of to use genetic information as a natural experiment. A second methodological contribution is to test the over-identifying restrictions for lagged sibling's BMI and to show that it does indeed pass these tests. Given that a number of previously published papers have used siblings' BMI as the sole identifying instrument, this is reassuring. Limitations, though, of genetic information are that it is expensive to collect and certain genotypes may have low prevalence. Both can lead to low power. In addition, because genes can affect several dimensions of behavior, it is critical to test the exogeneity assumption rigorously.

Although the focus of this paper is on genetic determinants of BMI in mid-teens, we know that environmental factors also influence BMI. A challenge for future research will be to control for the endogeneity of BMI in a way that accounts for both genetics and time-varying environmental factors that affect BMI. Such an analysis may also help determine the relative strength of genetics and environmental factors in determining BMI as people age.

\section{ACKNOWLEDGEMENTS}

This project was funded by the Demography and Economics of Aging Research Center grant from the National Institute on Aging (P30 AG04001). We thank participants in seminars at the Triangle Health Economics Workshop, Harvard University, Michigan University, the Southeastern Health Economics Working Group, and the International Health Economics Association World Congress for their helpful comments. David Bishai, David Blau, Phil DeCicca, Barbara Eberth, and two anonymous referees also provided thoughtful suggestions. The authors have no financial or personal relationships between themselves and others that might bias their work. This study received IRB approval from UNC at Chapel Hill, number 05-1413.

This research uses data from Add Health, a program project designed by J. Richard Udry, Peter S. Bearman, and Kathleen Mullan Harris, and funded by a grant P01-HD31921 from the Eunice Kennedy Shriver National Institute of Child Health and Human Development, with cooperative funding from 17 other agencies. Special acknowledgment is due to Ronald R. Rindfuss and Barbara Entwisle for assistance in the original design. Persons interested in obtaining data files from 
Add Health should contact Add Health, Carolina Population Center, 123 W. Franklin Street, Chapel Hill, NC 27516-2524 (addhealth@unc.edu). No direct support was received from grant P01-HD31921 for this analysis.

\section{REFERENCES}

Averett S, Korenman S. 1996. The economic reality of the beauty myth. Journal of Human Resources 31: 304-330. Baum CL, Ford WF. 2004. The wage effects of obesity: a longitudinal study. Health Economics 13: 885-899.

Behrman JR, Rosenzweig MR. 2001. The returns to increasing body weight. PIER Working Paper 01-052.

Blundell JE. 1977. Is there a role for serotonin (5-hydroxytryptamine) in feeding? International Journal of Obesity 1(1): 15-42.

Brown III HS, Pagan JA, Bastida E. 2005. The impact of diabetes on employment: genetic IVs in a bivariate probit. Health Economics 14(5): 537-544.

Cawley J. 2000. An instrumental variables approach to measuring the effect of body weight on employment disability. Health Services Research 35(5): 1159-1179.

Cawley J. 2004. The impact of obesity on wages. Journal of Human Resources 39(2): 451-474.

Chou SY, Grossman M, Saffer H. 2004. An economic analysis of adult obesity: results from the behavioral risk factor surveillances system. Journal of Health Economics 23: 565-587.

Comuzzie AG, Allison DB. 1998. The search for human obesity genes. Science 280(5368): 1374-1377.

Conley D, Glauber R. Gender, body mass and economic status. NBER Working Paper 11343, May 2005.

Cutler DM, Glaeser EL, Shapiro JM. 2003. Why have Americans become more obese? Journal of Economic Perspectives 17(3): 93-118.

Ding W, Lehrer SF, Rosenquist JN, Audrain-McGovern J. 2006. The impact of poor health on education: new evidence using genetic markers. NBER Working Paper 12304.

Dow WH, Norton EC. 2003. Choosing between and interpreting the Heckit and two-part models for Corner solutions. Health Services \& Outcomes Research Methodology 4(1): 5-18.

Finkelstein EA, Fiebelkorn IC, Wang GJ. 2003. National medical spending attributable to overweight and obesity: how much, and who's paying? Health Affairs 22(4): W219-W226.

Fletcher JM, Lehrer SF. 2008. Using genetic lotteries within families to examine the causal impact of poor health on academic achievement. Yale University Working Paper.

Gortmaker SL, Must A, Perrin JM, Sobol AM, Dietz WH. 1993. Social and economic consequences of overweight in adolescence and young adulthood. New England Journal of Medicine 329: 1008-1012.

Guo G, North K, Choi S. 2006. DRD4 gene variant associated with body mass: The National Longitudinal Study of Adolescent Health. Human Mutation 27(3): 236-241.

Han E, Norton EC, Stearns SC. 2008. Weight and Wages: Fat versus lean paychecks. Health Economics, forthcoming.

Hoebel BG, Hernandez L, Schwartz DH, Mark GP, Hunter GA. 1989. Microdialysis studies of brain norepinephrine, serotonin, and dopamine release during ingestive behavior. Theoretical and clinical implications. Annals of the New York Academy of Sciences 575: 171-191.

Loh ES. 1993. The economic effects of physical appearences. Social Science Quarterly 74: 420-438.

Long AD, Reed R, Lehman G. 2006. The cost of lifestyle health risks: obesity. Journal of Occupational \& Environmental Medicine 48(3): 244-251.

MacDonald A, Stunkard J. 1990. Body mass indexes in British separated twins. New England Journal of Medicine 322: 1530 .

Morris S. 2006. Body mass index and occupational attainment. Journal of Health Economics 25(2): 347-364.

Morris S. 2007. The impact of obesity on employment. Labour Economics 14(3): 413-433.

Norton EC, Bieler GS, Ennett ST, Zarkin GA. 1996. Analysis of prevention program effectiveness with clustered data using generalized estimating equations. Journal of Consulting and Clinical Psychology 64(5): 919-926.

Pagan JA, Davila A. 1997. Obesity, occupational attainment, and earnings. Social Science Quarterly 78(3): 756-770. Philipson T. 2001. The world-wide growth in obesity: an economic research agenda. Health Economics 10: 1-7.

Price RA, Gottesman II. 1991. Body fat in identical twins reared apart: roles for genes and envrionment. Behavioral Genetics 21: 1-7.

Register CA, Williams DR. 1992. Labor market effects of marijuana and cocaine use among young men. Industrial Labor Relations Review 45: 435-448.

Ruhm CJ. 2000. Are recessions good for your health? Quarterly Journal of Economics 115(2): 617-650.

Ruhm CJ. 2003. Good times make you sick. Journal of Health Economics 22(4): 637-658. 
Sargent JD, Blanchflower DG. 1994. Obesity and stature in adolescence and earnings in young adulthood. Analysis of a British birth cohort. Archives of Pediatrics \& Adolescent Medicine 148(7): 681-687.

Snyder EE, Walts B, Perusse L, Chagnon YC, Weisnagel SJ, Rankinen T, Bouchard C. 2004. The human obesity gene map: the 2003 update. Obesity Research 12: 369-439.

Staiger D, Stock JH. 1997. Instrumental variables regression with weak instruments. Econometrica 65(3): 557-586.

Stunkard AJ, Harris JR, Pedersen NL, McClearn GE. 1990. The body-mass index of twins who have been reared apart. New England Journal of Medicine 322: 1483-1487.

US Department of Health and Human Services. 2001. Office of the Surgeon General. Public Health Service. The Surgeon General's call to action to prevent and decrease overweight and obesity. Accessed at February 28, 2005 from: http://www.surgeongeneral.gov/topics/obesity/calltoaction/CalltoAction.pdf.

Wolf A, Colditz GA. 1998. Current estimates of the economic cost of obesity in the United States. Obesity Res 6(2): 97-106. 